\title{
The Preferences of Non-Governmental Organizations to Sustainable Investment: Evidence from Emerging Equity Market
}

\author{
${ }^{1}$ Dwitya Aribawa, ${ }^{2}$ Nopphon Tangjitprom \\ ${ }^{1}$ Faculty of Business and Economic, Universitas Atma Jaya Yogyakarta, Indonesia. dwitya.aribawa@uajy.ac.id \\ ${ }^{2}$ Martin de Tours School of Management and Economics, Assumption University of Thailand
}

\begin{tabular}{l} 
ARTICLE DETAILS \\
\hline History \\
Revised format: November 2019 \\
Available Online: December 2019
\end{tabular}

\section{Keywords}

NGO Investment, Ownership,

Preference, SRI, the Indonesia

Stock Exchange

\section{JEL Classification:}

L31, G32, R53, R59

\begin{abstract}
From December 2015 to August 2018, the shares ownership of NGOs in the Indonesian equity market growing more than $80 \%$ for domestic and $120 \%$ for foreign. This study is aim to empirically test the NGO investment preferences in the Indonesia Stock Exchange based on the unique data set of free float shares ownership by NGOs in Indonesia Stock Exchange. The authors identify the impact of the firm size, firm liquidity level and recognition of sustainability as factors that imply the preferences of the foreign NGOs ownership in the Indonesia equity market. A new dataset from Indonesia evidence addresses insight of the importance to analyze the preference of NGO investors' ownership in the stock market. In this study, the researchers examine two models to test the impact of market capitalization, liquidity and recognition of sustainability on the subsequent of NGO shares ownership. The analysis of stock ownership model performs by ordinaryleast-squares (OLS) regression approach. Robustness test confirmed that the data do not contain any of window dressing and trade discreteness effects. The main result of this study shows that foreign NGO prefers to hold more ownership on the firms with recognition of sustainability. There were also found that foreign NGOs prefers to holdings fewer variety stocks, bigger market capitalization compared to domestic NGOs. This study contributes to the debate of the important role of NGOs to foster a better investment environment in the emerging equity market. It also may help Indonesia Stock Exchange and Indonesia
\end{abstract}

(C) 2019 The authors, under a Creative Commons Attribution-Non Commercial 4.0

Corresponding author's email address: dwitya.aribawa@uajy.ac.id

Recommended citation: Aribawa, D., Tangjitprom, N., (2019).The Preferences of Non-Governmental Organizations to Sustainable Investment: Evidence from Emerging Equity Market. Journal of Accounting and Finance in Emerging Economies, 5 (2), 313-324

DOI: $10.26710 /$ jafee.v5i2.933

\section{Introduction}

Investment is a significant element of household behavior. Changing how to invest in a sense would change household behavior. Non-governmental organizations (NGOs) with shareholder power believe 
that it has the intention of pushing and encouraging businesses in order to adopt more sustainable practices. Refers to (Kong et al. 2002), Shareholder Action Network (SAN) that is initiated by NGOs is seen as a tool to scaling stock ownership power for a good change (i.e. Good governance). The NGOs collaboration with socially responsible investment (SRI) groups addresses to encourage and inform institutional and individual shareholders to exercise their power for the sake of good governance and sustainability of the firm. Furthermore, there is a phenomenon of the active role of institutional and individual investors demanding more SRI group, since it is one of the fastest-growing investment sectors.

Green and sustainable finance offer a promising future for global stock exchanges. It is seen from the significant growth of green finance products over the decades. In addition, green bond and green equity indices have better performance compare to non-green bonds or equity indices. Notwithstanding, sustainable investment initiatives are still in the early stages. It infers that this phenomenon would arise significant growth opportunities for exchanges and market stakeholders to strengthen their competitive position in sustainability matters (Sustainable Stock Exchange Initiative 2016).

Recognition of sustainable aspect of the corporation through indices has become a feature of the global capital market. Sustainable investment in Asia is growing increasingly 32.5\% of the market capitalization from 2012 to 2014. Specifically, in South-East Asia, there are only two stock exchange indices from Indonesia and Malaysia and one combined ASEAN Index (CSR Asia, 2016). The development of sustainable investment in South East Asia countries relies on government policies initiatives and corporate practices. Each country has a different sustainability landscape and approaches regarding policy and regulation, voluntary expectations and government incentives. This study focuses on one of the three aspects of this landscape, which is voluntary expectations that come from NGOs to enhance the sustainability approach to firms and investors in Indonesia.

Previous institutional studies ignore the internal condition of a country, which show has an important role in shaping reforms in ESG (environment, social responsibility, governance) aspects. The presences of ESG in the national context are a complex and dynamic process involving the interaction between different actors with their own interests (Ahmad and Mahmood 2015). These resolutions of sustainable investment are increasing the attention of institutional investors, small and large shareholders, and company executives. NGOs believe has a significant role in this novelty, using their status as advocates, advisors, and push for changing the policy (Guay, Doh, and Sinclair 2004).

In the emerging market, foreign institutional investors would increase their invested capital in preference to profitable, growing and larger firms (Kansil and Singh 2017). Meanwhile, the influential institutional ownership of the firm's indicators of sustainability depends on the economic condition. There is a demand for a study to measure the extent to which of institutional investors selection on socially responsible investments (Buchanan, Cao, and Chen 2018). There is a lack of study that explores the role and preference of specific institutional investment, especially NGOs in the emerging capital market.

NGOs are known to have an intense concern to the Environmental, Social and Governance (ESG) issues in investment. For that reason, this study is aim to empirically test the NGO investment preferences in the Indonesia Stock Exchange based on the unique data set of free float shares ownership by NGOs in Indonesia Stock Exchange. The authors identify the impact of the firm size, firm liquidity level and recognition of sustainability as factors that imply the preferences of the foreign NGOs ownership in the Indonesia equity market.

\section{Literature Review}

\subsection{Institutional Ownership}


Hester (1994) arises the phenomena regarding the evolving role of institution, instrument, and markets. Allen and Santomero (1997) argued that the cost-benefit of participation in the stock market became an important consideration in understanding the institution activities and particularly their focus on risk management. It supports the argument of different investment pattern of institutional investment regarding the point of view of risk management across nations (Prowse, 1990).

Modern stakeholder's theory underlined that it is not only about maximizing the wealth, but also unleashing the importance of power, urgency, and legitimacy of stakeholders. Managing that three elements closely related to the corporate environment and governance (Mitchell, Wood, and Agle 1997). Ryan and Schneider (2003) addressed re-concentration of ownership and control spawned by the institutional investing influence the management in the context of the modern firm. Moreover, the shift in foreign institutional investor standing and complexity of corporate landscape has been fundamentally transformed (Huang and Zhu 2015).

Institutional investors seem to prefer to invest in a firm with specific characteristics. Foreign institutions with direct stock investment seem to have a tendency to invest in a firm with large size, high level of liquidity and global recognition (Dahlquist and Robertsson 2001). Firms with higher ownership by institutions with no underlying interests (independent) are seen to have higher in valuations, better financial performance, and efficient in capital allocation, which infers the institution's actively monitoring corporations (Ferreira and Matos 2008). In addition, macroeconomic factors such as currency return also influence the institutional investors' money flow in the capital market (Froot and Ramadorai 2005).

The typology of institutional investors which is identified by Ferreira and Matos (2008) characterize institutional investors with differences of "colors" in terms of their ability to actively monitor corporate policies and decisions. The first typology of institutional investors is based on the origin, Domestic and Foreign Institutional Ownership. The second comes from the institution type, Independent Institutional Ownership (e.g. mutual fund managers and investment advisers) and Grey Institutional Ownership (e.g. bank trusts, insurance companies, pension funds and endowments or Non-Government Organization). This study focuses on the preference of domestic and foreign NGOs (grey institutional) ownership.

When the executives behave as rational agents to maximize shareholders wealth, the primary concern will be to create additional values for their shareholder's interests. Theoretically, executives of the company have to respond to NGOs shareholder's pressure to balance the profits and environmental aspects (people and planet) with consistency (Spar and Mure 2003). The preferences of shareholder ownership rely on specific variables that affect the perceived value which leads to the decision to invest, hold or sell the shares (Petersen and Vredenburg 2009). Based on that assumption, institutional investors tend to prefer socially aligned organizations to invest in their capital, this study explored to what extent to which the preference of socially linked institution (such as NGO) investment preferences in a stock market.

\subsection{Sustainable Investment}

Good governance that leading data transparency in this empowered technological era has become easier and cheaper. For that reason, the investment in assets featured with balancing profit and non-profit aspects is driven with promising movement and growing premium during decades. ESG investing allows investors to express their own values and to ensure that their savings and investments reflect their preferences, without compromising on returns (Forbes, 2018).

The term ESG investment par to sustainable investing, socially responsible investing (SRI), missionrelated investing or negative investment screening practice. ESG investment is engaged to the mixed stakeholders' perspective. From a firm perspective, ESG related policy requires complex strategic planning due to its direct relations to decisions with a long-term impact, including production technology, 
the use natural resources, and the social dimension, which refers to fulfill both interests of the business environment (van Duuren, Plantinga, and Scholtens 2015).

From individuals' point of view, ESG investing offers the opportunity for sustainable growth and shareholders activism (i.e. voting rights) for good governance and environment. And for policymakers, it should be a welcome market-led development that ensures that the common good does not get lost in short-term profit making at any cost. In general, ESG information is seen as modern tools to manage risk. For that reason, there is a concern from the global investor community to developing various methods for integrating ESG information optimally into investment practices (van Duuren et al. 2015). Related to this study, institutional investors increase the awareness of ESG investment in order to identify companies that are well positioned for the future and to avoid those which are likely to underperform. Many conventional fund managers (i.e. pension fund manager) have already adopted features of responsible investing in the investment process.

Harvard Business School global surveys (Amel-Zadeh and Serafeim 2017) arises the insight for the direction of ESG investment in the future. There is client demand for sustainable investment or as part of their product development process. Investors believe that ESG metrics provide useful information more on risks management. The uniqueness of sustainable investment data leads to ESG investors exhibiting different ESG investment styles. Furthermore, this study expects to identify the ESG investment styles of NGO's which related to certain preferences of stock selection.

The successful business today emerged from an organization that able to bring an innovative solution that tied to sustainability issues. From a company point of view, there is an effort to become a sustainable business that called "use a global presence" which closely related to recognition of company in a global context. Multinational corporations (MNCs) gained an advantage to experiences sustainability practices overseas in order to make certain alignment to the business. Meanwhile, the governments in developing countries have become concerned about the sustainability aspects and encouraged companies to introduce a sustainable standard (i.e. GRI) and the next level of sustainable products \& processes (Nidumolu, Prahalad and Rangaswami 2009). Furthermore, these initiatives lead to strategic Corporate Social Responsibility (CSR) projects that address to solve the problem of the natural environment and society.

Developing countries push voluntary basis sustainability reporting for a corporation (especially public company) which addresses the importance of market education and engagement approach related to sustainable investment. Sustainability reporting closely related to companies' activities that adopt environmental and ethical management standards and practices. These initiatives lead a corporation to gain credibility for the stakeholders and set the sustainability standard for the industry. Nevertheless, as with sustainability reporting in developed countries, there is a lack of a system delivering market-relevant information related to risk management that is incorporated into decision-making for investors (United Nations Environment Program 2016).

According to Corporate Knights (2016) report series from 2012-2016, stock exchanges sustainability recognition was ranked based on the disclosure, growth, and timeliness. The data used in the analysis was obtained from Bloomberg's ESG database based on indicators of energy use, carbon emissions, water use, waste generation, rate of employee injury, rate of employee turnover and personnel costs. As shown in figure 1 below, there is a notable improvement of sustainability disclosure ranking in South East Asia Region, specifically from Stock Exchange of Thailand and Bursa Malaysia. Meanwhile, Indonesia Stock Exchange is still lagged behind. 


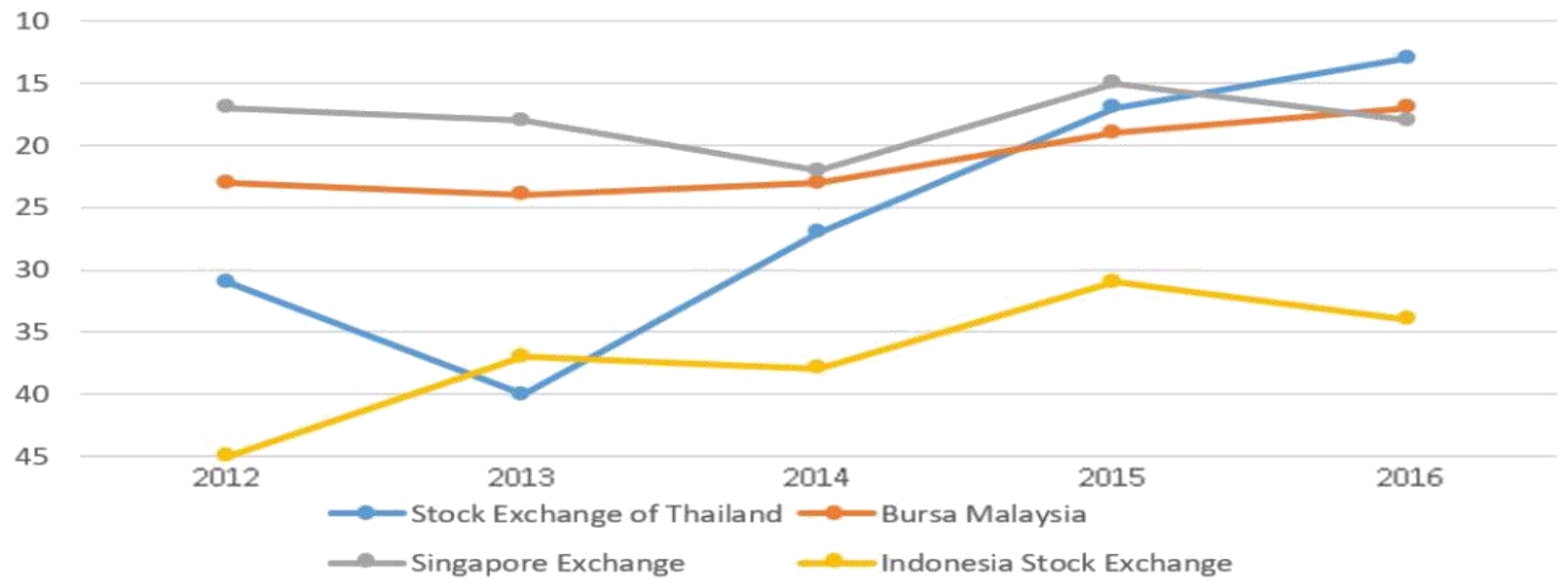

Source: Corporate Knights Sustainability Disclosure Ranking Figure 1: Ranking the South East Asia's Stock Exchanges Sustainability Disclosure (2012-2016)

The key aspect highlighted in global sustainability closely tied to the demands and concerns of foreign institutional investors to demonstrate best practice in corporate governance. Sustainability indices are also a popular way to recognize sustainability initiative among firms in stock exchanges. Many countries are developing indices that integrate social and environmental issues. Meanwhile, the indices tend to operate as a public recognition of good business practice without concern of the basis for a financial mechanism. However, the development of global sustainability indices has driven the development of locally relevant sustainability criteria and the capacity to assess investment practices (United Nations Environment Program, 2016).

As of June 2009, in an effort to develop sustainable initiatives in Indonesia, KEHATI foundation and Indonesia Stock Exchange have launched SRI KEHATI Index. This index follows the standard and regulation based on Sustainable and Responsible Investment (SRI) principles. Interestingly, a selection mechanism for the companies to be included in SRI KEHATI Index conduct every six months by both negative exclusion business practice and fundamental condition including several key financial aspects (KEHATI Foundation 2009). As the result, companies with the highest score declared to eligible into SRI KEHATI Index. This study accounted recognition of sustainable firm in Indonesia by firm appearances on SRI KEHATI Index.

In sum, the uniqueness of NGOs as institutional investors in the equity market indicates potential differences to the preferences of stock selection. However, there is a lack previous study that explains the preferences of NGOs in sustainable investment practices. Due to the high exposure of sustainable investment in emerging market and lack of study explore the role of NGO as an institutional investor in equity market; we propose two hypotheses that would test in the null form:

H1 Recognition of sustainability does not affect NGO shares ownership

H2 Recognition of sustainability does not affect NGO growth of invested capital

\section{Research Methods}

The sample utilized in the study is gathered from The Indonesia Central Custodian Depository (KSEI) and Indonesia Stock Exchange (IDX) in the period of September 2015 - August 2018. The raw data includes monthly shares ownership for domestic and foreign institutions and individual investors, including NGOs in all listed firms, stock price, number of shares outstanding, market capitalization and transaction volume 
of tradable shares. In addition, the recognition of firm sustainability gathered from the firm inclusion on SRI KEHATI index.

As this study is looking for the growth of invested capital, the short period of holding shares and missing month of ownership data are excluded. In addition, the small portion of NGOs invested capital as low as IDR50,000,000 (around \$3,000) is excluded from the sample which is an indication of low engagement of shareholders to concern on firm policy and decision making. In addition, firms that present incomplete information on the required variables will be excluded from the sample.

Based on our recent data of free-float shares ownership in the Indonesian equity market during 2015 2018 , respectively ownership of NGO's growth more than $80 \%$ for domestic and $120 \%$ for foreign NGOs. Unique dataset from Indonesia evidence addressing insight of the importance to analyze the preference of NGO ownership in the stock market.

Institutional investors prefer to invest capital into a firm with specific characteristics. The measurement of NGOs preference in this study is shown by the amount of share ownership and the growth of invested capital in a specific period. Meanwhile, the predecessor direct stock investment for NGOs investment modified from Dahlquist and Robertsson (2001) model which are assessing the size, liquidity, and recognition of sustainability firm. Previous study Haladu and Salim (2017) found that the aspect of social recognition to sustainability has better to explain the phenomena in sustainability situation compared to environmental reporting. For that reason, recognition of sustainability of firm chosen instead to GRI (Global Reporting Initiative) performance indicators in this study to represent sustainable investment variable.

Furthermore, two models in this study test the impact of market capitalization, liquidity and recognition of sustainability on the subsequent of NGO shares ownership. The analysis of stock ownership model likely performs with ordinary-least-squares (OLS) regression approach (Abrahamson and De Ridder, 2015) with robustness test in window dressing and trade Discreteness effects (Sias et al. 2006). The regression model is described as follows:

$$
\begin{aligned}
& \text { Own }(\text { ngo } i, t)=\operatorname{logit}\{b 0+b 1 \operatorname{cap}(\text { firm } i, t)+b 2 \operatorname{liq}(\text { firm } i, t)\}+b 3 \operatorname{sust}(\text { firm } i, t) \\
& \Delta \operatorname{Investcap}(\text { ngo } i, t)=b 0+b 1 \operatorname{cap}(\text { firm } i, t)+b 2 \operatorname{liq}(\text { firm } i, t)+b 3 \operatorname{sust}(\text { firm } i, t)
\end{aligned}
$$

Own(NGO i, t) — NGO shares ownership in company (i), month (t).

$\Delta$ Investcap(NGO $i, t)$ - the growth of NGO invested capital in company (i), month ( $t$ ). Cap(firm i,t) — market capitalization of company (i) in month (t).

Liq(firm i,t) Sust(firm i,t) — transaction volume of company (i) in month (t).

Sust(firm i,t) - a dummy variable for firm recognition of sustainability from the firm (i) appearances on SRI KEHATI Index in month $(\mathrm{t})$.

\section{Results and Analysis}

\subsection{Descriptive statistics}

There are gathered 10.899 possible observations from the monthly data of NGOs ownership in Indonesia from 2015-2018. Interestingly, 70\% of observations come from domestic NGOs due to diversified shares ownership and tendency to invest a small amount of capital into small or the mid-capitalization firms. Table I reports the descriptive statistics during December 2015 - August 2018 which describes the difference of preferences between foreign and domestic NGOs ownership in term of amount of invested capital, numbers of firm invested, percentage of big capitalization firms invested, percentage of LQ 45 
indexed firms invest the and percentage of SRI KEHATI index firms invested. This study focuses to analyze the foreign NGO's stock ownership preferences in Indonesia which follow the approach of the previous study that selects foreign institution as research object due to the establishment of specific investment selection in developing countries equity market (Rhee and Wang 2009).

The full panel data consist of 1764 observations with 49 stocks that have 36 months consecutive shares ownership of foreign NGO's from September 30, 2015, to August 31, 2018.

\section{Table 1: Descriptive Statistics}

\begin{tabular}{|c|c|c|c|c|c|c|c|}
\hline \multicolumn{2}{|c|}{ Period } & \multirow{2}{*}{$\begin{array}{l}\text { Invested capital } \\
\text { (in IDR) } \\
2,333,641,704,442\end{array}$} & \multirow{2}{*}{$\begin{array}{l}\text { Growth } \\
-\end{array}$} & \multirow{2}{*}{$\begin{array}{l}\text { Firms } \\
\text { Invested } \\
87\end{array}$} & \multirow{2}{*}{$\begin{array}{l}\text { Big } \\
\text { cap } \\
\text { firms } \\
74 \%\end{array}$} & \multirow{2}{*}{$\begin{array}{l}\text { LQ45 } \\
\text { Index } \\
\text { Invested } \\
69 \%\end{array}$} & \multirow{2}{*}{$\begin{array}{l}\text { SRI } \\
\text { KEHATI } \\
\text { Index } \\
\text { Invested } \\
60 \%\end{array}$} \\
\hline \multirow{4}{*}{ 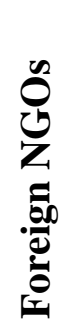 } & Dec-15 & & & & & & \\
\hline & Dec-16 & $4,435,060,718,132$ & $90.05 \%$ & 79 & $76 \%$ & $64 \%$ & $52 \%$ \\
\hline & Dec-17 & $5,166,226,909,581$ & $16.49 \%$ & 104 & $72 \%$ & $80 \%$ & $72 \%$ \\
\hline & Aug-18 & $6,724,329,800,745$ & $30.16 \%$ & 89 & $74 \%$ & $67 \%$ & $60 \%$ \\
\hline \multirow{4}{*}{ 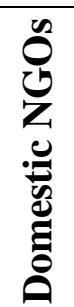 } & Dec-15 & $3,721,350,196,807$ & - & 204 & $44 \%$ & $89 \%$ & $80 \%$ \\
\hline & Dec-16 & $4,845,169,471,570$ & $30.20 \%$ & 207 & $47 \%$ & $91 \%$ & $80 \%$ \\
\hline & Dec-17 & $6,507,918,549,785$ & $34.32 \%$ & 214 & $49 \%$ & $91 \%$ & $96 \%$ \\
\hline & Aug-18 & $6,475,985,208,392$ & $-0.49 \%$ & 221 & $54 \%$ & $96 \%$ & $100 \%$ \\
\hline
\end{tabular}

\subsection{Findings}

The final panel data is tested for whether this assumption is valid for the random effects estimator is based on the Hausman test (Brooks, 2014). The viability of using fixed effect or random effect can be decided using Hausman test having the null hypothesis as, Ho: Random effects are consistent and efficient. This result is shown in table 2 below (Prob.) Cross-section random value $<0,05$ for the first and second model, which infer the null hypothesis is rejected by the result. For that reason, the first and second model which simulated from 1764 data sets has a fixed firm effect. Fixed effect models are appropriate to consider a specific set of firms with limited to the behavior of these firms (Baltagi, 2005).

Table 2: Hausman Test: Testing for Fixed or Random Affect

\begin{tabular}{|l|l|l|l|}
\hline \multicolumn{4}{|c|}{ Dependent Variable: Shares Ownership (Model 1) } \\
\hline \multicolumn{4}{|c|}{ Test cross-section random effects } \\
\hline Test Summary & Chi-Sq. Statistic & Chi-Sq. d.f. & Prob. \\
\hline Cross-section random & 77.947709 & 3 & 0.0000 \\
\hline Dependent Variable: Invested Capital Growth (Model 2) & Prob. \\
\hline Test cross-section random effects & Chi-Sq. Statistic & Chi-Sq. d.f. & \\
\hline Test Summary &
\end{tabular}




\begin{tabular}{|l|l|l|l|}
\hline Cross-section random & 20.837510 & 3 & 0.0001 \\
\hline
\end{tabular}

Table 3 reports the coefficients of the regression with a recognition of sustainability as a dummy variable. The coefficient of the dummy variable is positive and statistically significant at the convention level for panel A, which can be interpreted as the positive effect of the firm inclusion on the sustainability index to shares ownership preference of foreign NGOs.

Compared to the previous model of Dahlquist and Robertsson (2001), the adjusted R square is obviously higher and the F-test for the overall model is significant at 1 percent and 5 percent. The result from fixedeffect ordinary least squares analysis of the first model shows the preferences of foreign NGOs on stock ownership in Indonesia equity market significantly influence by the level of liquidity, size, and recognition of firm sustainability.

For that reason, this evidence contributes to the investment preferences for typology institutional investors' theory (Ferreira and Matos, 2008), which specifically to the NGOs that is classified as grey investors group. This group was defined as investors with more loyal to corporate management and without reacting to management actions that are not in line with the interests of shareholders. In the other words, this type of institution is characterized as "pressure-sensitive" or 'passive' institutional investors (Almazan et al., 2005; Brickley et al., 1988).

Table. 4 reports the coefficients of the regression of the growth of invested capital as the dependent variable. The result literally shows the preferences of NGOs add or reduce the invested capital in the equity market significantly influence by market capitalization of the firm. In addition, the preferences of NGOs Invested Capital Growth for firms with large market capitalization (more than Rp50 trillion or around $\$ 3$ billion) is also significantly influenced by the recognition of sustainability. Besides, liquidity level significantly influences NGOs Invested Capital Growth in small and medium firm sizes. For that reason, there are possible monthly trading activities occurred by foreign NGOs in medium and small size stocks.

In theory of trusting the stock market, the lack of trust explains why investors do not participate in the stock ownership in the absence of any friction. There is a difference in trust across investors and countries to invest in the stock market (Guiso, Sapienza and Zingales, 2008). For that reason, findings from panel B confirm that foreign NGO's investors have differences in trusts when conducting direct investment in the Indonesia stock market.

The results show that foreign NGOs preferences of investment growth only in the stocks with proper liquidity and with relatively big market capitalization. In addition, it can be inferred that the role of NGOs in Indonesia Stock Market is still limited to opportunism or speculator (Bekaert and Harvey, 2000) rather than activism to initiate changes for the firm governance and likelihood of stock market. In the other words, the role of shareholder power that using money becomes a tool for a good change (Kong et al., 2002) is not yet shown in Indonesia stock market.

NGOs is advisedly to work with socially responsible investment (SRI) groups to encourage and inform shareholders to exercise their power (Kong et al., 2002). NGOs need to exercise their incremental role in order to support sustainable stock exchange initiatives. To conclude, NGOs should be taking on a more active role by maximizing the role of ownership by promoting more SRI initiatives, influence the sustainability policy of corporation and address stock exchanges concern regarding sustainability issues. 
Table 3: Results of panel least regression for Panel A (fixed effect)

\begin{tabular}{|c|c|c|c|c|c|}
\hline \multicolumn{6}{|c|}{ PANEL A: NGO's Stock Ownership } \\
\hline Variables & Full Panel & $\begin{array}{c}\text { Exclude } \\
\text { Window } \\
\text { Dressing } \\
\text { Period }\end{array}$ & Large & Middle & Small \\
\hline \multirow[t]{2}{*}{ Constant } & $-7.329871 * * *$ & $-8.089349 * * *$ & $\begin{array}{l}- \\
60.41533 * * *\end{array}$ & $13.35838 * * *$ & $27.37329 * * *$ \\
\hline & $(2.402235)$ & $(2.606778)$ & $(1.017208)$ & $(2.460681)$ & $(8.522928)$ \\
\hline \multirow[t]{2}{*}{ Liquidity } & $-0.069801 * *$ & $-0.062581 *$ & - $0.052068 * * *$ & - $0.377027 * * *$ & 0.081796 \\
\hline & $(0.029725)$ & $(0.032307)$ & $(0.012967)$ & $(0.067252)$ & $(0.072865)$ \\
\hline \multirow[t]{2}{*}{ Size } & $0.756456 * * *$ & $0.785081 * * *$ & $2.341771 * * *$ & $0.384469 * * *$ & -0.430652 \\
\hline & $(0.077301)$ & $(0.083085)$ & $(0.027532)$ & $(0.057397)$ & $(0.291403)$ \\
\hline \multirow{2}{*}{$\begin{array}{l}\text { Recognition of } \\
\text { Sustainability }\end{array}$} & $2.049662 * * *$ & $1.301656 * * *$ & $0.047885^{* * *}$ & - & - \\
\hline & $(0.285149)$ & $(0.309938)$ & $(0.002287)$ & - & - \\
\hline $\begin{array}{l}\text { Adjusted } \quad \text { R- } \\
\text { Square }\end{array}$ & 0.815243 & 0.834039 & 0.255476 & 0.108312 & 0.006093 \\
\hline F-Statistic & $153.5342 * * *$ & $131.2695 * * *$ & $13.31226 * * *$ & $5.123201 * * *$ & 0.999718 \\
\hline
\end{tabular}

Notes: $*, * *, * * *$ denote significance at the $10 \%, 5 \%, 1 \%$ level. The value in the bracket (value) is a standard error.

Table 4: Results of panel least regression for Panel B (fixed effect)

\begin{tabular}{|c|c|c|c|c|c|}
\hline \multicolumn{6}{|c|}{ PANEL B: NGO's Invested Capital Growth } \\
\hline Variables & Full Panel & $\begin{array}{c}\text { Exclude } \\
\text { Window } \\
\text { Dressing } \\
\text { Period } \\
\end{array}$ & Large & Middle & Small \\
\hline \multirow[t]{2}{*}{$\mathrm{C}$} & $-1.97 \mathrm{E}+10^{* * * *}$ & $-2.31 \mathrm{E}+10^{* * * *}$ & $\begin{array}{l}- \\
1.15 \mathrm{E}+11 * * *\end{array}$ & $-2.32 \mathrm{E}+09$ & 42685728 \\
\hline & $(7.00 \mathrm{E}+09)$ & $(7.99 \mathrm{E}+09)$ & $(6.34 \mathrm{E}+09)$ & $(3.13 \mathrm{E}+09)$ & $(1.25 \mathrm{E}+08)$ \\
\hline \multirow[t]{2}{*}{ Liquidity } & -3.515399 & -5.261625 & 3.043153 & $\begin{array}{l}- \\
6.297290 * * *\end{array}$ & $\begin{array}{l}- \\
0.335611 * * *\end{array}$ \\
\hline & $(4.855289)$ & $(5.919134)$ & (3.294986) & $(1.706263)$ & $(0.071650)$ \\
\hline Size & $0.000323 * * *$ & $0.000385 * * *$ & $0.000294 * * *$ & $0.000258 * * *$ & $-2.50 \mathrm{E}-05$ \\
\hline
\end{tabular}




\begin{tabular}{|l|l|l|l|l|l|}
\hline & $(5.54 \mathrm{E}-05)$ & $(6.27 \mathrm{E}-05)$ & $(1.50 \mathrm{E}-05)$ & $(4.88 \mathrm{E}-05)$ & $(2.47 \mathrm{E}-05)$ \\
\hline $\begin{array}{l}\text { Recognition } \\
\text { of } \\
\text { Sustainability }\end{array}$ & $-2.70 \mathrm{E}+09$ & $-1.91 \mathrm{E}+09$ & $8.65 \mathrm{E}+09^{* * *}$ & - & - \\
\cline { 2 - 6 } & $1.71 \mathrm{E}+10$ & $(1.89 \mathrm{E}+10)$ & $3.63 \mathrm{E}+08$ & - & - \\
\hline $\begin{array}{l}\text { Adjusted R- } \\
\text { Square }\end{array}$ & 0.013679 & 0.030205 & 0.008667 & 0.041552 & 0.015767 \\
\hline F-Statistic & $1.479425^{* *}$ & $1.807348^{* * *}$ & $1.313699 * * *$ & $2.471622^{* * *}$ & $0.081282^{*}$ \\
\hline
\end{tabular}

Notes: $*, * *, * * *$ denote significance at the $10 \%, 5 \%, 1 \%$ level. The value in the bracket (value) is a standard error.

\subsection{The Robustness Test}

This study follows Sias, Starks, and Titman (2006) approach to confirm the robustness of the data. The approach from Sias et al., (2006) seems to be fit with this study due to the application of monthly data set and the fact that we do not know when exactly the change in ownership occurs. There are two approaches to justify the robustness of the data that applied in this research paper, (1) Potential Bias due to Window Dressing and (2) Trade Discreteness.

To identify whether there any potential bias of window dressing effects, authors excluding the last quarter (October, November, and December) of the year firm i data for shares ownership, market capitalization, liquidity and SRI KEHATI Index Appearing (Dummy). As a result of the fixed effect estimation for the exact same model, respectively table 3 and table 4 in column two shows no significant difference from the full sample (1764 observations) and sample that exclude window dressing periods (1323 observations). In the other words, a window dressing bias is not affected to the stock ownership and the invested capital growth of NGOs in Indonesia stock market.

The aggregate institutional ownership data are available on a monthly basis. The possible bias could be found due to undiscovered when exactly the change in ownership occurs. For a given security, it is possible that the entire change in ownership occurs the first day, the last day, or somewhere in between a month.

Nonetheless, to ensure that our results are not sensitive to such potential patterns, we conducted the analysis for small, medium, and large stocks. Stocks are sorted into three equal-sized groups based on the average annual market capitalization of firm separately. Furthermore, it hypothesizes that institutions account for most of the invested capital in the large stocks, changes in institutional ownership are more likely to be spread out over the months (trade discreteness) in medium and small stocks. In addition, recognition of sustainability variable only exists on large stocks.

Thus, the results are systematically biased by the discreteness in changes in NGO ownership, then the small stock analysis should differ substantially from the medium and large stock analysis. Meanwhile, the differences in firm size reveal little evidence that discreteness of ownership changes affects the results of this study. In sum, the estimates by firm size suggest that the relation between monthly changes in NGO ownership and investment preferences is align to the institutional ownership theory that argued institutions has tendency to hold a stock with specifically with bigger market capitalization in relative longer periods in order to control and arise activism (Appel, Gormley, and Keim, 2016; Bushee, 2001; Bushee, Goodman and Sunder, 2018; Gillan and Starks, 2000). In the other words, there is a rising possibility of NGOs as one of the agent to rise activism to foster sustainability practice for public firms and market.

\section{Conclusion and Future Research}


In this paper, the authors highlight that there is a positive effect on the firm inclusion on sustainability index towards ownership preference of foreign NGOs. The result from fixed-effect ordinary least squares analysis shows the preferences of foreign NGOs stock ownership in Indonesia equity market significantly influence by the level of liquidity, size, and recognition of firm sustainability. However, NGOs growth of invested capital during the observation periods only prefers for a stock with specific bigger market capitalization.

Due to the limitation of observations, this study only observes for respective 36 monthly periods from 2015-2018. Notwithstanding, the result shows free of window dressing effect and trade discreteness on different firm sizes. The selection of Indonesia somewhat become questionable due to the relatively small amount of NGOs investment compare to other institutions. In addition, NGOs investment regulation in Indonesia limited to article 7 section 1, 2 and 3 of the Indonesian Law No. 16, 2001, which does not specifically address the foreign NGO ownership in the capital market. For that reason, authors suggest the Indonesian government body such as Financial Services Authority (OJK) to address this issue regarding the regulation update of NGO shares ownership in the stock market in order to foster the likelihood of Sustainable Stock Exchange in Indonesia.

Additionally, there is lack of ESG related training offers in Indonesia (Sustainable Stock Exchanges, 2018). For that reason, this study encourages academia and practitioner to involve in the ESG investment training in Indonesia. Besides, there are demanding community investment and the development of green investment products (Bonds, Indices and Derivatives) in emerging market in which NGOs is seen as a catalyst for the sustainable related initiatives (Sustainable Stock Exchange Initiative, 2016).

Ultimately, the emerge of positive screening rather than negative screening in sustainable investment (Amel-Zadeh and Serafeim, 2017), segregation of institutional investors related to sustainability issues (Ferreira and Matos, 2008) and activism role of institutional ownership in developing stock market (Guay et al. 2004) become an incremental element to be identified in the further study. Those factors could be significant to the sustainable investment body of knowledge and practices.

\section{References}

Allen, F., \& Santomero, A. M. (1997). The Theory of Financial Intermediation. Journal of Banking and Finance, 21(11-12), 1461-1485.

Amel-Zadeh, A., \& Serafeim, G. (2017). Why and How Investors Use ESG Information: Evidence from a Global Survey. HBS Working Paper. https://doi.org/10.2139/ssrn.2925310

Appel, I. R., Gormley, T. A., \& Keim, D. B. (2016). Passive investors, not passive owners. Journal of Financial Economics, 121(1), 111-141.

Baltagi, B.H. (2005). Econometric Analysis of the Panel Data. (3rd Edition). United Kingdom: John Wiley \& Sons Ltd.

Bekaert, G., \& Harvey, C. R. (2000). Foreign speculators and emerging equity markets. The Journal of Finance, 55(2), 565-613.

Brooks, C. (2014). Introductory econometrics for finance. Cambridge university press.

Buchanan, B., Cao, C. X., \& Chen, C. (2018). Corporate social responsibility, firm value, and influential institutional ownership. Journal of Corporate Finance, 52, 73-95. https://doi.org/10.1016/j.jcorpfin.2018.07.004

Bushee, B. J. (2001). Do institutional investors prefer near-term earnings over long-run value?. Contemporary Accounting Research, 18(2), 207-246.

Bushee, B. J., Goodman, T. H., \& Sunder, S. V. (2018). Financial Reporting Quality, Investment Horizon, and Institutional Investor Trading Strategies. The Accounting Review.

CSR Asia. (2016). Sustainability Disclosure in ASEAN: The ASEAN Extractive Sector. Report Paper. 
Journal of Accounting and Finance in Emerging Economies

Vol.5, No 2, December 2019

Corporate Knights. (2016). Measuring Sustainability Disclosure: Ranking the World's Stock Exchanges. Annual Report Series.

Dahlquist, M., \& Robertsson, G. (2001). Direct foreign ownership, institutional investors, and firm characteristics. Journal of Financial Economics, 59(3), 413-440. https://doi.org/10.1016/S0304-405X(00)00092-1

Ferreira, M. A., \& Matos, P. (2008). The colors of investors' money: The role of institutional investors around the world. Journal of Financial Economics, 88(3), 499-533. https://doi.org/10.1016/j.jfineco.2007.07.003

Forbes. (2018). The Remarkable Rise of ESG. Retrieved from https://www.forbes.com/sites/georgkell/2018/07/11/the-remarkable-rise-of-esg/

Froot, K. A., \& Ramadorai, T. (2005). Currency Returns, Intrinsic Value, and Institutional-Investor Flows. The Journal of Finance, 60(3), 1535-1566.

Rhee, S. G., \& Wang, J. (2009). Foreign institutional ownership and stock market liquidity: Evidence from Indonesia. Journal of Banking \& Finance, 33(7), 1312-1324.

Gillan, S. L., \& Starks, L. T. (2000). Corporate governance proposals and shareholder activism: The role of institutional investors. Journal of financial Economics, 57(2), 275-305.

Guay, T., Doh, J., \& Sinclair, G. (2004). Non-Governmental Organizations, Shareholder Activism, and Socially Responsible Investments: Strategic, Ethical and Governance Implications. Journal of Business Ethics, 52(1), 125-139. https://doi.org/10.1023/B

Guiso, L., Sapienza, P., \& Zingales, L. (2008). Trusting the stock market. the Journal of Finance, 63(6), 2557-2600.

Hester, D. D. (1994). On the theory of financial intermediation. De Economist, 142(2), $133-149$. https://doi.org/10.1007/BF01388162

Kansil, R., \& Singh, A. (2017). Firm characteristics and foreign institutional ownership: Evidence from India. Institutions and Economies, 9(2), 35-53.

KEHATI Foundation (2009, June 9). SRI KEHATI Index [Official Website]. Retrieved from http://kehati.or.id/indeks-sri-kehati/

Kong, N., Salzmann, O., Steger, U., \& Ionescu-somers, A. (2002). Moving Business / Industry Towards Sustainable Consumption: The Role of NGOs. European Management Journal, 20(2), 109-127.

Mitchell, R. K., Wood, D. J., \& Agle, B. (1997). Toward a Theory of Stakeholder Identification and Salience : Defining the Principle of Who and What Really Counts. Academy of Management Review, 22(4), 853886. https://doi.org/10.5465/AMR.1997.9711022105

Nidumolu, R., Prahalad, C. K., \& Rangaswami, M. R. (2009). Why sustainability is now the key driver of innovation. Harvard business review, 87(9), 56-64.

Petersen, H. L., \& Vredenburg, H. (2009). Morals or Economics? Institutional Investor Preferences for Corporate Social Responsibility. Journal of Business Ethics, 90(1), 1-14. https://doi.org/10.1007/s10551-009-0030-3

Prowse, S. D. (1990). Institutional investment patterns and corporate financial behavior in the United States and Japan. Journal of Financial Economics, 27(1), 43-66. https://doi.org/10.1016/0304-405X(90)90020-Z

Ryan, L. V., \& Schneider, M. (2003). Institutional Investor Power and Heterogeneity: Implications for Agency and Stakeholder Theories. Business \& Society, 42(4), 398-429. https://doi.org/10.1177/0007650303260450

Sias, R. W., Starks, L. T., \& Titman, S. (2006). Changes in institutional ownership and stock returns: Assessment and methodology. The Journal of Business, 79(6), 2869-2910.

Sustainable Stock Exchange Initiative. (2016). How stock exchanges can grow green finance. Action Plan Paper.

United Nations Environment Programme. (2016). Green finance for developing countries. The Inquiry Report of Design of a Sustainable Financial System.

van Duuren, E., Plantinga, A., \& Scholtens, B. (2015). ESG Integration and the Investment Management Process: Fundamental Investing Reinvented. Journal of Business Ethics, 138(3), 525-533. https://doi.org/10.1007/s10551-015-2610-8 